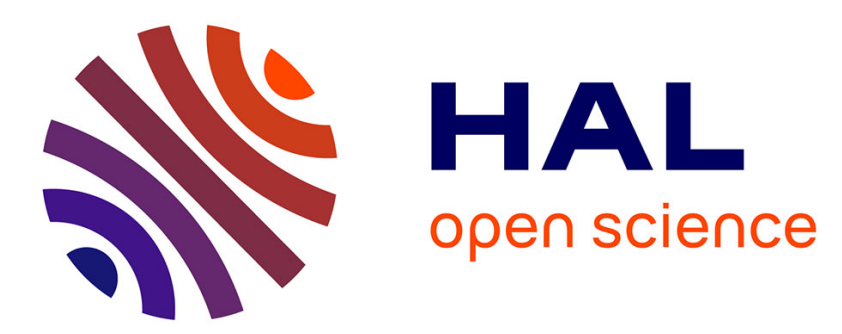

\title{
Dissolution of coccolithophorid calcite by microzooplankton and copepod grazing
}

\author{
A. N. Antia, K. Suffrian, L. Holste, M. N. Müller, J. C. Nejstgaard, P. \\ Simonelli, Y. Carotenuto, S. Putzeys
}

\section{- To cite this version:}

A. N. Antia, K. Suffrian, L. Holste, M. N. Müller, J. C. Nejstgaard, et al.. Dissolution of coccolithophorid calcite by microzooplankton and copepod grazing. Biogeosciences Discussions, 2008, 5 (1), pp.1-23. hal-00297955

\section{HAL Id: hal-00297955 \\ https://hal.science/hal-00297955}

Submitted on 2 Jan 2008

HAL is a multi-disciplinary open access archive for the deposit and dissemination of scientific research documents, whether they are published or not. The documents may come from teaching and research institutions in France or abroad, or from public or private research centers.
L'archive ouverte pluridisciplinaire HAL, est destinée au dépôt et à la diffusion de documents scientifiques de niveau recherche, publiés ou non, émanant des établissements d'enseignement et de recherche français ou étrangers, des laboratoires publics ou privés. 


\section{Dissolution of coccolithophorid calcite by microzooplankton and copepod grazing}

A. N. Antia ${ }^{1}$, K. Suffrian ${ }^{1}$, L. Holste ${ }^{2}$, M. N. Müller ${ }^{1}$, J. C. Nejstgaard ${ }^{3}$, P. Simonelli ${ }^{4}$, Y. Carotenuto ${ }^{5}$, and S. Putzeys ${ }^{6}$

${ }^{1}$ Leibniz Institute for Marine Sciences (IFM-GEOMAR), Düsternbrooker Weg 20, 24105 Kiel, Germany

${ }^{2}$ Institute for Hydrobiology and Fisheries Research, Olbersweg 24, 22767 Hamburg, Germany

${ }^{3}$ Department of Biology, UNIFOB, P.O.Box 7800, 5020 Bergen, Norway

${ }^{4}$ University of Bergen, Department of Biology, P.O.Box 7800, 5020 Bergen, Norway

${ }^{5}$ Stazione Zoologica "A. Dohrn", Villa Comunale 1, 80121 Naples, Italy

${ }^{6}$ Facultad de Ciencias del Mar, Universidad de Las Palmas de Gran Canaria, 35017 Tafira

Baja - Las Palmas, Spain

Calcite dissolution by microzooplankton and copepod grazing

A. N. Antia et al.

Received: 19 November 2007 - Accepted: 26 November 2007 - Published: 2 January 2008

Correspondence to: A. N. Antia (aantia@ifm-geomar.de)

Title Page

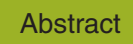

Introduction

Conclusions

Tables

References

Figures

$1<$

I

4

Back

Close

Printer-friendly Version

Interactive Discussion 


\section{Abstract}

Independent of the ongoing acidification of surface seawater, the majority of the calcium carbonate produced in the pelagial is dissolved by natural processes above the lysocline. We investigate to what extent grazing and passage of coccolithophorids 5 through the guts of copepods and the food vacuoles of microzooplankton contribute to calcite dissolution. In laboratory experiments where the coccolithophorid Emiliania huxleyi was fed to the rotifer Brachionus plicatilis, the heterotrophic flagellate Oxyrrhis marina and the copepod Acartia tonsa, calcite dissolution rates of $45-55 \%, 37-53 \%$ and $5-22 \%$ of ingested calcite were found. We ascribe higher loss rates in microzooplankton food vacuoles as compared to copepod guts to the strongly acidic digestion and the individual packaging of algal cells. In further experiments, specific rates of calcification and calcite dissolution were also measured in natural populations during the PeECE III mesocosm study under differing ambient $\mathrm{pCO}_{2}$ concentrations. Microzooplankton grazing accounted for between 27 and $70 \%$ of the dynamic calcite stock being lost per day, with no measurable effect of $\mathrm{CO}_{2}$ treatment. These measured calcite dissolution rates indicate that dissolution of calcite in the guts of microzooplankton and copepods can account for the calcite losses calculated for the global ocean using budget and model estimates.

\section{Introduction}

20 Globally, ca. 0.8-1.4 GT calcium carbonate (Feely et al., 2004) is biogenically produced in the global ocean, most of it by pelagic organisms. Coccolithophorids, calcifying microalgae, are the primary producers of pelagic carbonates, forming massive blooms that can be seen from space. Yet $50-80 \%$ of this calcite is dissolved above the lysocline, and does not have any immediate effect on carbonate export to the sediments or $\mathrm{CO}_{2}$ uptake by the ocean (Chung et al., 2003; Iglesias-Rodriguez et al., 2002; Milliman et al., 1999). The process responsible for this dissolution, that is the primary
BGD

$5,1-23,2008$

Calcite dissolution by microzooplankton and copepod grazing

A. N. Antia et al.

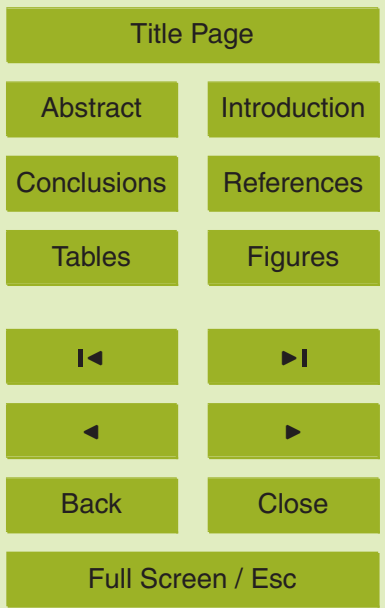

Printer-friendly Version

Interactive Discussion 
fate of pelagically produced calcite, have not yet been quantified, though grazing by zooplankton has been implicated by Milliman (1999). Grazing by copepods has been shown to result in significant dissolution of ingested calcite as shown in experimental (Harris, 1994) and modelling (Jansen and Wolf-Gladrow, 2001) studies.

5 Since individual coccolithophorids have negligible sinking speeds, it is their packaging in fecal pellets that causes them to leave the surface, and aggregates packed with coccolithophorid remains are a main conduit of calcite to the sediments.

Microzooplankton grazing pressure on microalgae generally exceeds that of copepods, and the minipellets of microzooplankton contribute to the sinking particulate 10 flux, making the process at least potentially dominant in assessing the fate of coccolithophorids. Yet there is to our knowledge no estimate on the dissolution of the coccolithophorid calcite that is ingested by microprotozoans, although grazing by microprotozoans in the natural environment plays a dominant role in the uptake of biogenic pelagic calcite.

15 Dissolution of calcite in copepod guts, in which $\mathrm{pH}$ reaches mildly acidic values (Pond et al., 1995; but see Lapernat et al., 2003) is an important loss process (Jansen and Ahrens, 2004). However, calcite dissolution in the guts of microprotozoans, in which single food items are ingested by phagocytosis into digestive vacuoles and subjected to strongly acidic conditions (Fok et al., 1982) has not been investigated. We hypothesize that the digestive process in microzooplankton food vacuoles could play a dominant role in bulk calcite losses. and investigate this in the laboratory and the field.

In this paper we have three goals: Firstly, to quantify the dissolution of calcite due to grazing of two microzooplankton species and a copepod on the coccolithophorid Emiliania huxleyi in controlled laboratory experiments. Secondly, to estimate the dis25 solution of calcite due to microzooplankton grazing during the PeECE III mesocosm experiments. Thirdly, to see if the effects of different $\mathrm{CO}_{2}$ levels in the mesocosms are reflected in differing calcite production and dissolution rates.

\section{BGD}

5, 1-23, 2008

Calcite dissolution by microzooplankton and copepod grazing

A. N. Antia et al.

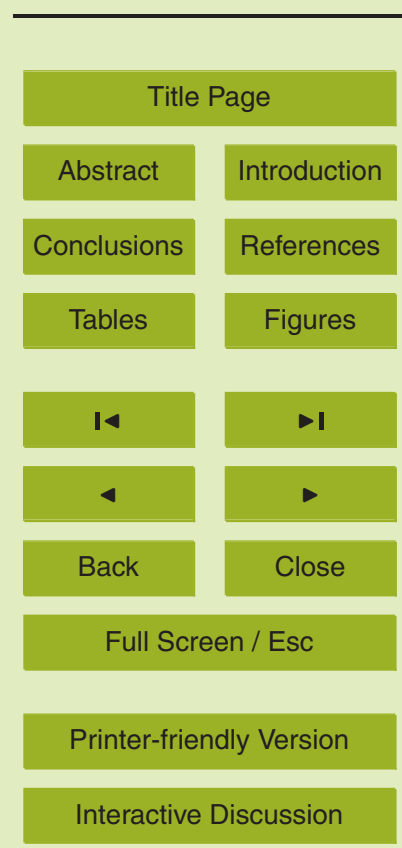

EGU 


\section{Materials and methods}

\subsection{Laboratory experiments}

Grazing of microzooplankton on Emiliania huxleyi (E. hux):

Cultures of $E$. hux (strain CCMP 371 obtained from the Bigelow Laboratory, West

5 Boothbay Harbor, Maine) were kept in autoclaved 2I Polycarbonate bottles with 1.6 I filtered $(0.2 \mu \mathrm{m})$ Baltic Sea water at a salinity of ca. 15 . Nutrients were added as per the recipe for $\mathrm{f} / 2$ medium after Guillard (1975), but diluted 25 -fold with seawater (i.e. to an end concentration of $\mathrm{f} / 50$ ) with no silicate. Cultures were subjected to a $14: 10 \mathrm{~h}$ light:dark cycle of $150 \mu \mathrm{E} / \mathrm{m}^{2} / \mathrm{s}$ at $14^{\circ} \mathrm{C}$. Seawater was buffered to a pH value of $8.1-$

10 8.2. Cell numbers were routinely counted using a coulter counter and experiments were always conducted during exponential growth. Cultures were gently rotated in a zooplankton incubator to keep the cells in suspension.

As microzooplankton grazers we used the heterotrophic flagellate Oxyrrhis marina (O. marina) that is an avid grazer and readily ingests $E$. hux. O. marina was fed $E$. hux for at least 10 growth cycles before commencement of the experiments to adjust food vacuoles to the coccolithophorid. For the experiments, $O$. marina cultures were fed with an exponentially growing $E$. hux culture to an end concentration of ca. 4500 . marina and $4 \times 10^{3}$ E. hux per ml medium in $250 \mathrm{ml}$ culture flasks. Flasks were gently rotated during the 6-day experiments and samples taken for cell counts and calcium analyses daily. $\mathrm{pH}$ of the medium was monitored daily.

A metazoan microzooplankter used was the rotatoria Brachionus plicatilis (B. plicatilis). B. plicatilis was reared on $E$. hux for three weeks prior to the experiments and microscopical examination showed large, coccolithophorid-filled vacuoles within the animals. Experiments were conducted in 2.3-I Nalgene bottles with an initial concentration of $4.6 \times 10^{3} \mathrm{E}$. hux ml $\mathrm{m}^{-1}$ and addition of $50 \mathrm{~B}$. plicatilis to $1.5 \mathrm{I}$ seawater. Bottles were gently bubbled to keep the algae in suspension. During the 6-day experiments samples were taken daily for cell counts and calcium measurements and $\mathrm{pH}$ was monitored in the flasks.

Calcite dissolution by microzooplankton and copepod grazing

A. N. Antia et al.

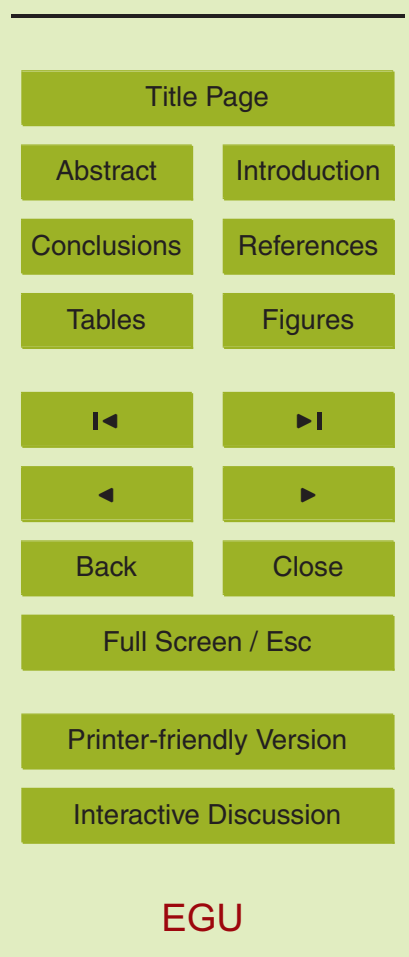


Copepod grazing on $E$. hux was measured in experiments using Acartia tonsa ( $A$. tonsa), a common Baltic copepod. A. tonsa was reared on $E$. hux for several generations before conducting the experiments. In parallel flasks exponentially growing $E$. hux cultures at a concentration of $3 \times 10^{3}$ ind $\mathrm{ml}^{-1}$ were put in 2.3-I Nalgene flasks to

5 which 30 copepods each were gently pipetted. Flasks were gently rotated on a rolling incubator. Since $E$. hux growth in light far exceeded grazing, cultures were placed in the dark after $48 \mathrm{~h}$. Samples were taken every second day for cell counts and calcium analyses.

For all the laboratory experiments, two experimental flasks and one control flask 10 containing algae at the concentration of the experimental flasks were run in parallel.

Cell counts were conducted in triplicate with a Coulter Counter connected to a Coulter multisizer II (analyses were performed using the MULTI 32 program by Beckton Dickson) and values are presented as means of the triplicate measurements $(\mathrm{sd}= \pm 7 \%)$. Samples of $50-100 \mathrm{ml}$ were filtered from each bottle on to acid-washed 15 polycarbonate filters (poresize: $0.2 \mu \mathrm{m}$ ) and stored at $-20^{\circ} \mathrm{C}$. Filters were put into $0.25 \mathrm{~N} \mathrm{HCl}$ and left for $5 \mathrm{~min}$ in an ultrasonic bath to dissolve all $\mathrm{CaCO}_{3}$. Calcium was measured using Inductively coupled Plasma- optical emission spectroscopy (ICPOES).

Dissolution of calcite in each flask was calculated by assuming algae in the control 20 and treatment flasks grew at the same rates and by calculation of the net loss of calcite over the entire incubation period. Results are expressed as \% initial calcite lost over the experimental time.

\subsection{PeECE III mesocosm experiments}

The PeECE III mesocosm experiments were conducted to determine the effects of 25 $\mathrm{pCO}_{2}$ concentrations corresponding to the present day (350 $\left.\mu \mathrm{atm}\right)$, future $(700 \mu \mathrm{atm})$ and far future $(1050 \mu \mathrm{atm})$ in triplicate mesocosms each. For a description of the mesocosm setup and sampling, see Schulz et al. (2007).

\section{BGD}

$5,1-23,2008$

Calcite dissolution by microzooplankton and copepod grazing

A. N. Antia et al.

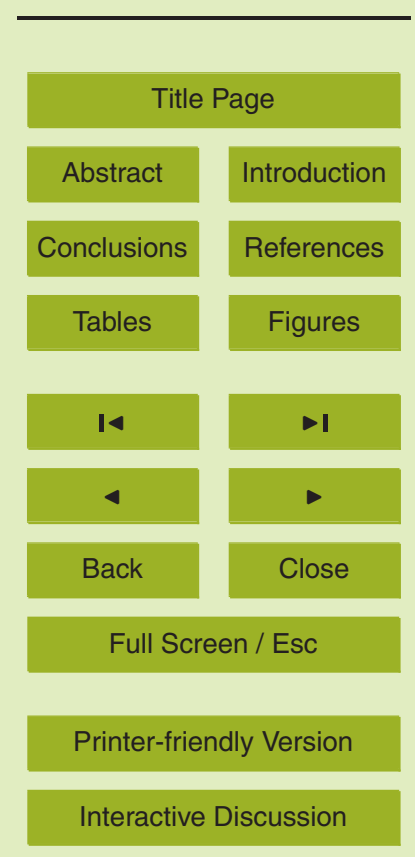

EGU 
In a separate paper in this issue, Suffrian et al. (2007) ${ }^{1}$ report on the trends in algal production and microzooplankton grazing in serial dilution experiments, after the method of Landry (1993), conducted in the mesocosms to which we refer for a detailed description of the methods used. Since these methods provide a powerful means of 5 estimating the production and loss of any variable that is of autotrophic origin and presuming losses through grazing, we used calcite as the measured variable to estimate its production and dissolution.

For the estimation of calcite production and grazing-associated losses ca. $50 \mathrm{ml} \mathrm{sam}$ ples were taken as for Chlorophyll (Chl) a from each of these experiments. The sam10 ples were gently filtered onto pre-acidified and rinsed Nucleopore filters of pore size $0.2 \mu \mathrm{m}$ under a vacuum pressure of $200-300 \mathrm{hPa}$. Filters were shock frozen by liquid nitrogen in cryovials and stored at $-80^{\circ} \mathrm{C}$ for later analysis of calcium by inductively coupled plasma optical emission spectrometry (ICP-OES). In this case, filters were extracted in $2 \mathrm{ml} 1 \mathrm{~N} \mathrm{HCl}$.

15 A total of twelve experiments were conducted over the course of the PeECE III experiments, four each in rotation from mesocosms 2,5 and 8 corresponding to $\mathrm{pCO}_{2}$ values of 1050,700 and $350 \mu$ atm respectively, resulting in non-simultaneous estimations of rates in each of the mesocosms.

\section{Results}

\subsection{Laboratory experiments on calcite dissolution}

In both experiments with microzooplankton grazers, grazing was very rapid within the first $48 \mathrm{~h}$, with $E$. hux numbers levelling off to very low concentrations thereafter

\footnotetext{
${ }^{1}$ Suffrian, K., Simonelli, P., Nejstgaard, J. C., Putzeys, S., Carotenuto, Y., Antia, A. N.: Microzooplankton grazing and phytoplankton growth in marine mesocosms with increased $\mathrm{CO}_{2}$ levels, Biogeosciences Discuss., submitted, 2007
}

\section{BGD}

$5,1-23,2008$

Calcite dissolution by microzooplankton and copepod grazing

A. N. Antia et al.

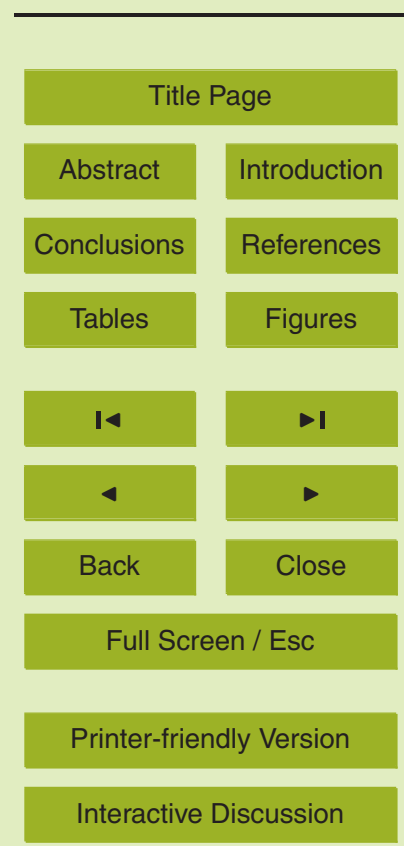

EGU 
(Fig. 1). At the end of the experiments, microscopic analysis of O. marina and B. plicatilis showed empty cells with few or no food vacuoles, and the algal concentrations were below the threshold concentrations for zooplankton growth that we saw in the pre-experiments. Calcium concentration and cell number followed the same temporal 5 trend for experiments with $B$. plicatilis and $O$. marina. In the experiment with $A$. tonsa the decrease in calcite was much lower than the decrease in cell numbers seen. The results of the experiments are summarized in Table 1. Whereas with both microzooplankton grazers high losses of calcite were seen (between 37 and $55 \%$ of the initial calcite was lost in $6 \mathrm{~d}$ ), calcite dissolution by the copepod $A$. tonsa was considerably 10 lower and more variable between experiments.

Ingestion rates of $E$. hux cells by $O$. marina and $B$. plicatilis were considerably lower than by $A$. tonsa (Table 1), suggesting a greater efficiency of dissolution in the food vacuoles of the microzooplankton grazers than in the copepod guts than indicated by the bulk dissolution rates alone. Assuming continuous ingestion, the average residence

15 time of $E$. hux in the food vacuoles and guts of $O$. marina, B. plicatilis and $A$. tonsa were on average $7 \mathrm{~h}, 2 \mathrm{~h}$ and $20 \mathrm{~min}$, respectively.

Scanning electron microscopy showed clear and significant signs both of mechanical damage to coccolithophorids and dissolution of coccoliths (Fig. 2). In the case of grazing by $O$. marina, (Fig. 2d) minipellets of ca. $5 \mu \mathrm{m}$ diameter and irregular shape were abundant in the treatments at the end of the experiments. These were clearly covered by an organic membrane, and spiny fragments of coccoliths were visible through the membrane.

Fecal aggregates of $B$. plicatilis (Fig. 2b) were much larger (ca. $12-15 \mu \mathrm{m}$ in diameter) and consisted solely of mechanically broken and partially dissolved coccolith fragments. For $B$. plicatilis, fecal aggregates largely lacked an organic membrane.

Copepod fecal pellets (Fig. 2e) were closely packed, membrane-covered aggregates. At close view, although coccoliths appeared to be mechanically damaged and some dissolution could be seen around the edges of the distal and proximal shield elements, many coccoliths still retained the inner tube and were clearly identifiable as

BGD

$5,1-23,2008$

Calcite dissolution by microzooplankton and copepod grazing

A. N. Antia et al.

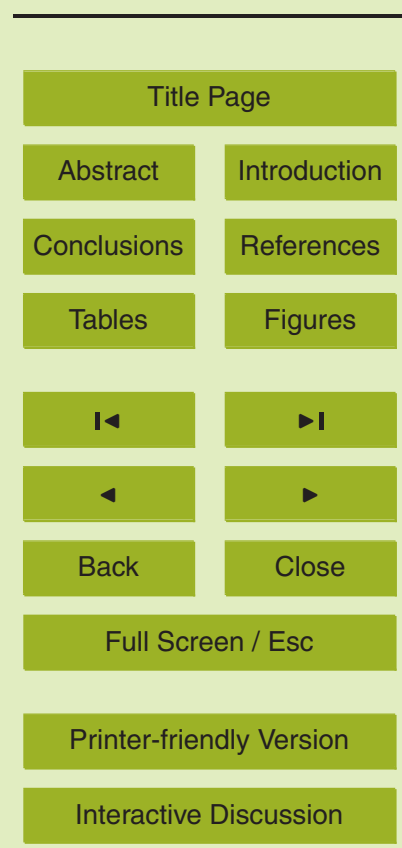

EGU 
Coefficients of calcite production and losses from the dilution experiments are presented in Table 2. Calcite production and losses are correlated (Fig. 3). The initial ex5 cess of production over loss during bloom build-up changes to an excess of loss over production in the post-bloom situation. Based on the bulk calcite measurements, between $60 \%$ and $5 \%$ of the calcite turnover ("dynamic standing stock" i.e. standing stock plus production) is lost due to microzooplankton grazing, with a strongly decreasing trend towards the end of the experiments. However, these results are deceptive, since the major part of calcite measured after the peak in $E$. hux abundance was in the form of free coccoliths or fragments that would not be ingested by microprotozoans. In order to account for this, we estimated the calcite in vital cells and used this value for further calculations. The standing stock of calcite in cells $\left(\mathrm{SS}_{\text {cells }}\right)$ was estimated by multiplying cell numbers with the average value of $1 \times 10^{-6} \mu \mathrm{mol} \mathrm{Ca} \mathrm{cell}^{-1}$, that was measured in a cultured isolate of $E$. hux from the PeECE III mesocosms (M. N. Müller, unpublished data). The difference between $\mathrm{SS}_{\text {cells }}$ and total calcite $\left(\mathrm{SS}_{\mathrm{tot}}\right)$ is the calcite in free liths $\left(\mathrm{Ca}_{\text {free }}\right)$. The temporal development of calcite standing stock in cells, $\mathrm{SS}_{\text {cells, }}$, and the contribution of free coccoliths $\mathrm{Ca}_{\text {free }}$ to total calcite standing stocks $\mathrm{SS}_{\text {tot }}$ are shown in Fig. 4. By the end of the experiment, less than $3 \%$ of total calcite was in vital cells.

20 We then recalculated the dissolution of calcite using the coefficients measured in the experiments but substituting $\mathrm{SS}_{\text {cells }}$ as the initial reference values (Table 3 ). With three exceptions, (experiments $1 \times \mathrm{d} 1,1 \times \mathrm{d} 20$, and $3 \times \mathrm{d} 15$, of which two, $1 \times \mathrm{d} 20$ and $3 \times \mathrm{d} 15$ have a low significance level of $p>0.05$ ), grazing results in a loss of calcite amounting to between $27 \%$ and $73 \%$ of the dynamic standing stock of calcite in $E$. hux cells.

\section{Calcite dissolution by microzooplankton and copepod grazing}

A. N. Antia et al.

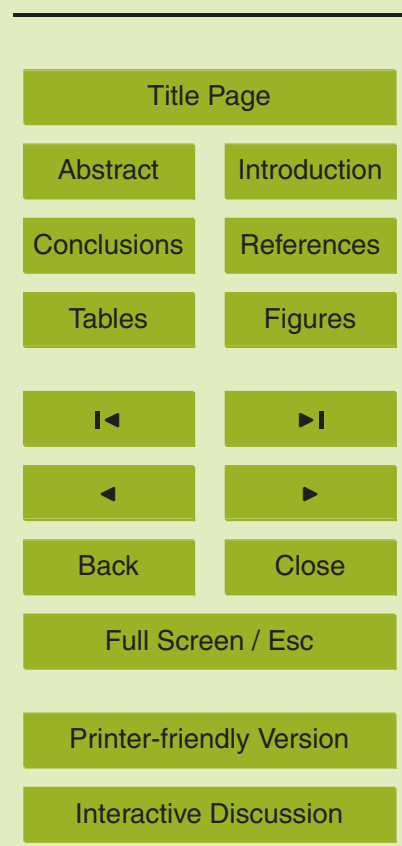




\section{Discussion}

Independent of the effects of changing seawater $\mathrm{pH}$ due to the anthropogenic rise in atmospheric $\mathrm{CO}_{2}$, large amounts of the naturally produced pelagic calcium carbonate are lost in the upper layers of the ocean, yet the rates of and processes responsible 5 for this depletion are poorly quantified or identified. Coccolithophorids are the major calcite producing organisms in the pelagial, and accumulations of their coccoliths have built massive calcite sediments at water depths above the lysocline. Although individual coccoliths have negligible sinking speeds, they find their way to the sea bed in densely packed fecal pellets of copepods and other macrozooplanton and in the sominipellets of microzooplankton. The fecal aggregates of copepods, appendicularia and other filter- feeding zooplankton are important transport vehicles of particles to the deep-sea and their dense freight of coccolithophorids is often seen in situ in mid-water sediment traps (Bathmann et al., 1987). Observations of intact coccoliths in copepod fecal pellets in deep-sea traps led to the assumption that they were not 15 subjected to dissolution (Bathmann et al., 1987; Honjo, 1976), yet most of the pelagic calcite produced is not exported vertically below the upper $1000 \mathrm{~m}$ (Millimann, 1999; Feely et al., 2002; Jansen et al., 2002), indicating that indeed dissolution must be the primary fate of pelagic calcium carbonate.

Although not preferentially ingested, probably due to their indigestible covering of coccoliths, coccolithophorids are readily grazed on by both copepods (Nejstgaard et al., 1994) and microzooplankton (Fileman et al., 2002), making ingestion their primary fate. Since digestion is primarily an acidic process dissolution of calcite in the guts and food vacuoles could be expected, and Harris (1994), estimated the loss of coccolithophorid calcite in copepod guts in the North Atlantic to be as high as $~ 70 \%$ of the ingested calcite. In a numerical modelling study of calcite dissolution in copepod guts, Jansen and Wolf-Gladrow (2001) identify gut $\mathrm{pH}$, gut clearance rate and temporal grazing pattern (grazing/non-grazing cycles) as being the key parameters that would determine how much calcite is dissolved during each passage through a copepod gut.

BGD

$5,1-23,2008$

Calcite dissolution by microzooplankton and copepod grazing

A. N. Antia et al.

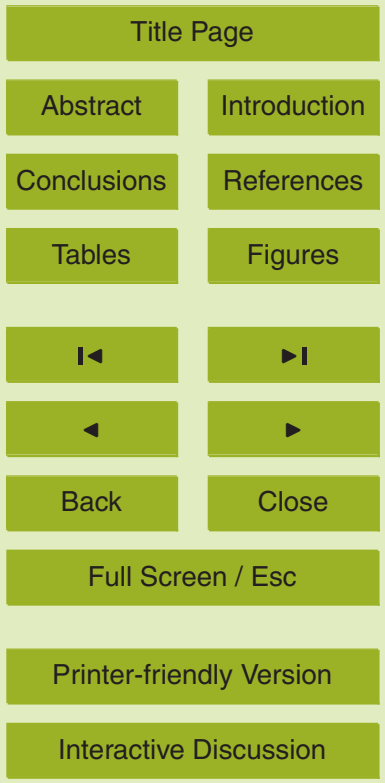

EGU 
Discluding the reingestion of fecal pellets, they calculate that only $15 \%$ calcite is lost, whereas successive coprophagy cycles can increase this to up to $70 \%$ losses. In our experiments we found variable calcite dissolution rates between the parallel experiments, resulting in between $5 \%$ and $22 \%$ dissolution of calcite, which agree with the 5 lower estimates of model studies. The passage time of E.hux in the guts of the copepod Acartia tonsa used in this study $(20 \mathrm{~min})$ is similar to the value assumed by Jansen and Wolf-Galdrow and gut passage times from the literature (e.g. Irigoien, 1998). Other factors that we did not investigate such as variations in grazing/starvation cycles, growth rate, feeding history, ingestion rate, and coprophagy may well affect gut $\mathrm{pH}$ and thus 10 dissolution. Feeding history particularly may play an important role, since gut enzymes are primed by the availability of food - further experiments would thus be needed to examine the range of dissolution that may be found under different conditions.

There is still considerable uncertainty as to the $\mathrm{pH}$ of the digestive tract of copepods. Using a direct measurement with microinjection of a $\mathrm{pH}$-sensitive dye into the guts of 15 live calanoid copepods, Pond et al. (1995) found a mean $\mathrm{pH}$ of 6.86 and 7.19 in the foreand hind guts of starved animals, respectively. When fed with coccolithophorids, the $\mathrm{pH}$ increased to mean values of 7.97 and 8.23 , respectively. The authors conclude that at least in parts of the guts, reduction of $\mathrm{pH}$ to about 6.1 would allow for calcite dissolution. In another study, Lapernat et al. (2003) fed fluorescein labeled yeast to measure gut $\mathrm{pH}$ in $C$. helgolandicus fed with $E$. huxleyi. This fluorescence method, developed by Ahrenz et al. (2001), showed low pH values, between 5.5 and 6 , in the middle-gut, but about $\mathrm{pH} 8$ at the beginning and the end of the gut. The lower values of $\mathrm{pH}$ could permit a partial dissolution of the coccoliths passing the gut. This is in keeping with the optima for digestive enzyme activities in copepods and other crustacea that range from acidic ( $\mathrm{pH} 5$ ) to basic (pH 8-9) (Bond, 1934; Mayzaud and Mayzaud, 1981; van Wheel, 1970). $\mathrm{pH}$ microenvironments within the guts would provide optimal digestive conditions for a variety of food types, and would in part expose digested food to acidic conditions conducive to calcite dissolution. It appears, thus, that the crucial variable of gut $\mathrm{pH}$ used in the modelling studies of Jansen and Wolf-Gladrow (2001) is poorly

\section{BGD}

$5,1-23,2008$

Calcite dissolution by microzooplankton and copepod grazing

A. N. Antia et al.

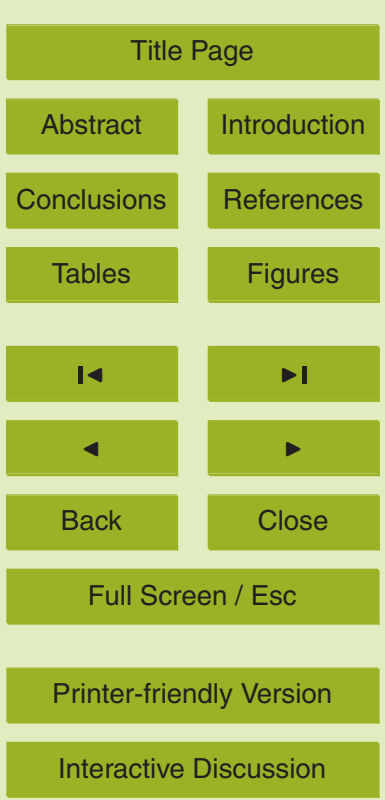

EGU 
constrained by measurements.

The relatively low dissolution of ingested $E$. hux in the guts of $A$. tonsa that we found is evident in the electron micrographs of their fecal pellets (Fig. 2). Although there are some signs of dissolution around the edges of the shield, the distinguishing inner 5 tube and central area of $E$. hux coccoliths were largely intact and visible. Mechanical damage and the larger surface area of the coccoliths thus exposed may accentuate their dissolution in the water column or make them more susceptible to dissolution on reingestion.

The role of microzooplankton grazing in causing dissolution of coccolithophorids has 10 previously been neglected, and the high rates found in this study, both in the laboratory and field experiments, indicate that this process may dominate the losses of pelagic calcite. Although Jansen and Wolf-Gladrow (2001) suggest that the volume of digestive vacuoles of protozoa are too small for dissolution to take place, this has not yet been experimentally investigated and does not appear to be the case.

15 Both microzooplankton used in this study (the metazoan rotifer and the protozoan flagellate) ingest their prey into discrete food vacuoles in which digestion takes place. The general process of feeding follows three main steps in microprotozoans; digestive vacuole formation through pinocytosis; acidification-condensation within the food vacuole, lysosomal fusion and digestion followed by vacuole defecation (Fok and Shockley, 1985). Measurements of $\mathrm{pH}$ in protozoan food vacuoles are rare, but in one study the time course of $\mathrm{pH}$ change in the food vacuoles in a model ciliate, Paramecium caudatum, showed a rapid drop to values of ca. pH 3 within 7 min of ingestion (Fok et al., 1982), At this level, dissolution of liths would be extremely rapid. Optima for enzymatic hydrolysis in Paramecium spp. guts were found to be well in the acidic range at a $\mathrm{pH}$

of ca. 5 (Fok, 1983); analogous measurements for marine species to the best of our knowledge do not exist, nor are measurements of the intracellular or intra-vacuole $\mathrm{pH}$ in marine species currently available.

The passage time for digestive vacuoles through the guts of marine ciliates has been estimated at between $30 \mathrm{~min}-5 \mathrm{~h}$ in bactivorous ciliates (Fenchel, 1975) and ca. $2 \mathrm{~h}$ in
BGD

$5,1-23,2008$

Calcite dissolution by microzooplankton and copepod grazing

A. N. Antia et al.

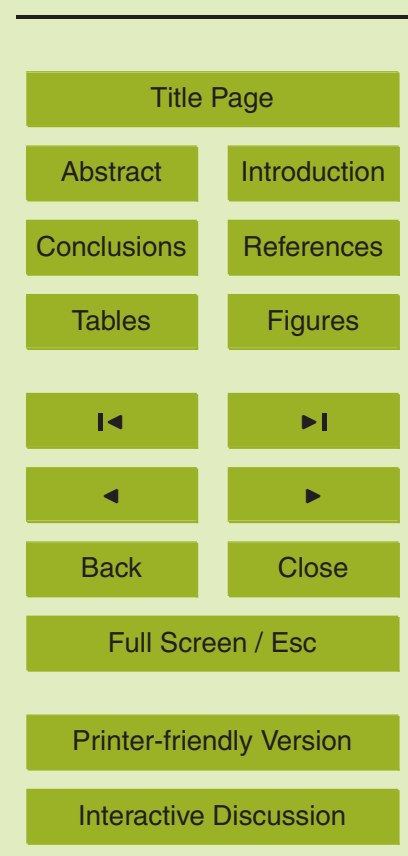

EGU 
the heterotrichous marine ciliate Fabrea salina (Capriulo and Degnan, 1991), in good agreement with the residence times of $E$. hux in the vacuoles of $B$. plicatilis and $O$. marina that we found in this study (Table 1 ).

The much higher dissolution rates (37-55\%) by microzooplankton than by the cope5 pod (5-22\%) may thus reflect the basic differences in the digestive process in these organisms. The dense packaging of coccolithophorids in copepod guts with the higher throughput rate does not have as corrosive an effect as the more prolonged exposure to the strongly acidic environment in microzooplankton vacuoles.

Scanning electron micrographs (Fig. 2) clearly reflect these differences, and the dis10 solution of the central area in the coccolith structure in fecal aggregates of $B$. plicatilis and $O$. marina are striking. The clear presence of a covering membrane in the minipellets of $O$. marina is also in contrast to the exposed detrital aggregates of $B$. plicatilis, and suggests that the mode of packaging on defecation will play an important role in further dissolution in the water column. Should minipellets be reingested, it is likely that dissolution would be even more rapid, possibly resulting in complete loss of the calcite.

Having established the high loss rates of calcite in microzooplankton vacuoles in laboratory experiments, we were interested in determining the importance of microzooplankton grazing to calcite turnover in the field. By using the serial dilution approach it was possible to simultaneously estimate calcification and calcite loss rates under varying $\mathrm{pCO}_{2}$ concentrations in the PeECE III mesocosms. We also wanted to examine whether $E$. hux growing under $2 \times$ and $3 \times$ present $\mathrm{pCO}_{2}$ concentrations would have an increased susceptibility to dissolution.

The close coupling of the specific constants of calcification and dissolution indicate the rapid grazing of $E$. hux in the mesocosms (Fig. 3). There was no difference in the rates between mesocosms with different $\mathrm{CO}_{2}$ levels - measured differences between mesocosm bags were likely reflecting the different sampling periods; for example whereas the $1 \times \mathrm{CO}_{2}$ treatment was sampled on day 1 , at the lag before growth, the first sampling of the $3 \times \mathrm{CO}_{2}$ mesocosm was on day 3 , when the bloom was already underway.

\section{BGD}

$5,1-23,2008$

Calcite dissolution by microzooplankton and copepod grazing

A. N. Antia et al.

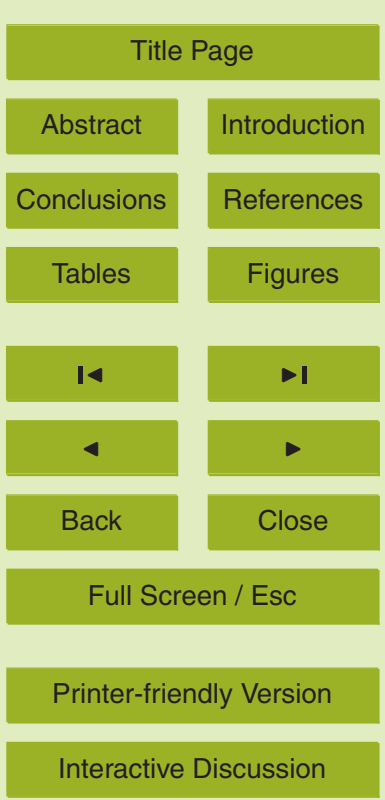

EGU 
When calculated on the basis of bulk calcite in the experimental bottles, the loss of between $30 \%$ and $60 \%$ calcite during the first 9 days of the experiments, when E.hux was in exponential growth, decreased abruptly to below $10 \%$ at the end of the experiment when E. hux numbers were negligible (Paulino et al, accepted). This trend is an 5 artefact of the measurements, since the bulk of calcite measured following the bloom was present as free coccoliths (Fig. 4). When estimating calcite dissolution based on the calcium in E. hux cells only, a much more consistent pattern is seen throughout the experiment with between $27 \%$ and $70 \%$ of the dynamic calcite standing stock being lost by microzooplankton grazing per day. Despite the scatter in the data, in part due 10 to the difficulty in measuring the smaller signal of vital cells against the large pool of free coccoliths, the range of dissolution is similar to that seen in our controlled culture experiments.

Ultimately, the dissolution of coccolithophorid calcite will depend on the exposure of the coccoliths to microenvironments undersaturated with respect to calcite. Direct measurements of the $\mathrm{pH}$ in zooplankton guts are required to better model and predict dissolution under different concentrations and types of predators. The presence of acidic microenvironments within sinking aggregates would further facilitate dissolution, though this would largely depend on their porosity. i.e. the capacity to maintain a gradient with the surrounding seawater. Although Jansen et al. (2002) state that porous marine aggregates would not be able to develop the gradients required to maintain $\mathrm{CaCO}_{3}$ undersaturation, this has not been directly explored.

The prominent role of microzooplankton in calcite turnover in the pelagial underpins their importance to biogeochemical cycling. Due to their short division times and high filtration rates, they respond rapidly to changes in prey abundance, resulting in 25 rapid recycling of autotrophic biomass and associated elements or minerals such as calcium carbonate. Microzooplankton are ubiquitous both in time and space in the marine environment and colonise almost all microhabitats including sinking amorphous aggregates, detrital particles and the sediment surface.

The bulk dissolution rates we show have implications for natural fluxes of pelagic

\section{BGD}

$5,1-23,2008$

Calcite dissolution by microzooplankton and copepod grazing

A. N. Antia et al.

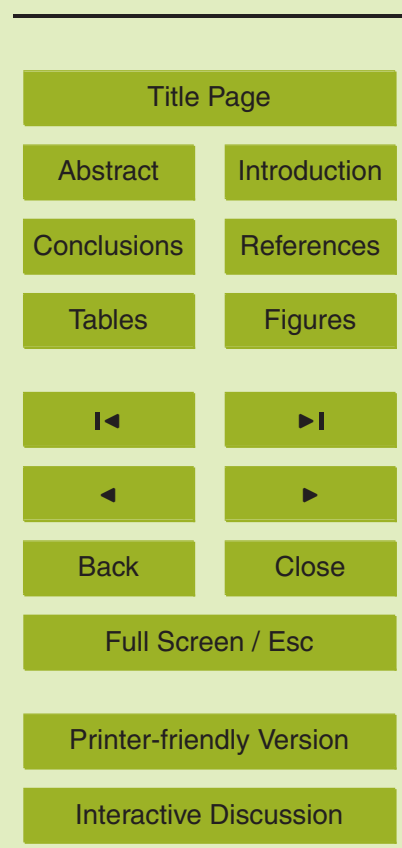

EGU 
autotrophic calcite entirely independent of acidification or other projected changes in sea surface chemistry. The rapid dissolution of calcite within the upper ventilated layer of the ocean also has implications on the net gradient in $\mathrm{pCO}_{2}$ betweeen the ocean and atmosphere (Antia et al., 2001). Thus, in addition to the effects on physiology that may 5 or may not affect net coccolithophorid calcification in the coming decades, changes in the food web associated with different grazer groups will play a role in net calcite losses. In addition to the many changes in marine food webs and biogeochemical cycles that have been postulated and projected in a changing $\mathrm{CO}_{2}$ world, it is thus important to understand and account for the large natural background signal of calcite losses in the 10 pelagial against which changes will take place.

Acknowledgements. The authors thank the participants of the PeECE III project for their support during the experiment. The staff at the Marine Biological Station, University of Bergen, in particular T. Sørlie and A. Aadnesen, and the Bergen Marine Research infrastructure (RI) are gratefully acknowledged for support in mesocosm logistics. R. Surberg is acknowledged

Y. Carotenuto was funded by the European Marine Research Station Network (MARS) Travel Award for Young Scientist 2004. J. C. Nejstgaard was supported by the Norwegian Research Council (NRC) project 152714/120 30.

\section{References}

Antia, A. N., Koeve, W., Fischer, G., Blanz, T., Schulz-Bull, D., Scholten, J., Neuer, S., Kremling, K., Kuss, J., Peinert, R., Hebbeln, D., Bathmann, U., Fehner, U., Conte, M., and Zeitzschel, B.: Basin-wide particulate carbon flux in the Atlantic Ocean: regional export patterns and potential for atmospheric $\mathrm{CO}_{2}$ sequestration. Global Biogeochem. Cy., 15, 845-862, 2001.

Bathmann, U. V., Noji, T. T., Voss M., and Peinert, R.: Copepod fecal pellets: Abundance, sedimentation and content at a permanent station in the Norwegian Sea in May/June 1986. Mar. Ecol.-Prog. Ser., 38, 45-51, 1987.

Bond, R. M.: Digestive enzymes of the pelagic copepod, Calanus finmarchicus ,Biol. Bull., 67, 461-465, 1934.
BGD

$5,1-23,2008$

Calcite dissolution by microzooplankton and copepod grazing

A. N. Antia et al.

Title Page

Abstract

Introduction

Conclusions

References

Tables

Figures

14

$\rightarrow$

4

Back

Close

Full Screen / Esc

Printer-friendly Version

Interactive Discussion 
Capriulo, G. M. and Degnan, C.: Effect of food concentration on digestion and vacuole passage time in the heterotrichous marine cilliate Fibrea salina, Mar. Biol., 110, 199-202, 1991.

Chung, S.-N., Lee, K., Feely, R. A., Sabine, C. L., Millero, F. J., Wanninkhof, R., Bullister, J. L., Key, R. M., and Peng, T.-H.: Calcium carbonate budget in the Atlantic Ocean 5 based on water column inorganic carbon chemistry, Global Biogeochem, Cy, 17(4),1-4, doi:10.1029/2002GB002001, 2003.

Feely, R. A., Sabine, C. L., Lee, K., Berelson, W., Kleypas, J. A., Fabry, V. J., and Millero, F. J.: Impact of Anthropogenic $\mathrm{CO}_{2}$ on the $\mathrm{CaCO}_{3}$ System in the Oceans, Science, 305, 362-366, 2004.

10 Fenchel, T.: The quantitative importance of the benthic microfauna of an arctic tundra pond, Hydrobiologia, 46, 445-464, 1975.

Fileman, E. S., Cummings, D. G., and Llewellyn, C. A.: Microplankton community structure and the impact of microzooplankton grazing during an Emiliania huxleyi bloom, off the Devon coast. J. Mar. Biol. Assoc. UK, 82, 359-368, 2002.

Fok, A. K.: An Inhibition and Kinetic Study of Acid Phosphatase in Paramecium caudatum and Paramecium tetraurelia. J. Protozool., 30, 14-20, 1983.

Fok, A. K., Lee Y., and Allen, R. D.: The Correlation of Digestive Vacuole pH and Size with the Digestive Cycle in Paramecium caudatum., J. Protozool., 29, 409-414, 1982.

Fok, A. K. and Shockley, B. U.: Processing of Digestive Vacuoles in Tetrahymena and the Effects of Dichloroisoproterenol. J. Protozool., 32, 6-9, 1985.

Guillard, R. R. L.: Culture of phytoplankton for feeding marine invertebrates. In: Culture of marine invertebrate animals, edited by: Smith, W. L. and Chanley, M. H., Plenum Press, New York, 29-60, 1975.

Harris, R. P.: Zooplankton grazing on the coccolithophore Emiliania huxleyi and its role in inorganic carbon flux, Mar. Biol, 119, 43-439, 1994.

Honjo S.: Coccoliths: production, transformation and sedimentation, Mar. Micropaleontol., 1, 65-79, 1976.

Iglesias-Rodriguez, M. D., Armstrong, R., Feely, R. A., Hood, R., Kleypas, J. A., Sabine, C. L., and Sarmiento, J. L.: Progress made in the Study of Ocean's Calcium Carbonate Budget.

30 EOS, Transactions, AGU 83, 365, 374-375, 2002.

Irigoien, X.: Gut clearance rate constant, temperature and initial gut contents: a review, J. Plankton Res., 20, 997-1003, 1998.

Jansen, $\mathrm{H}$. and Ahrens, M. J.: Carbonate dissolution in the guts of benthic deposit feeders: A

BGD

5, 1-23, 2008

Calcite dissolution by microzooplankton and copepod grazing

A. N. Antia et al.

Title Page

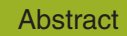

Introduction

Conclusions

Tables

References

Figures

14

$\rightarrow$

4

Back

Close

Full Screen / Esc

Printer-friendly Version

Interactive Discussion 
numerical model, Geochim. Cosmochim. Ac., 68, 4077-4092, 2004.

Jansen, H. and Wolf-Gladrow, D. A.: Carbonate dissolution in copepod guts:a numerical model, Mar. Ecol.-Prog. Ser., 221, 199-207, 2001.

Landry, M. R.: Estimating rates of growth and grazing mortality of phytoplankton by the dilution 5 method, in: Handbook of methods in aquatic microbial ecology, edited by: Kemp, P. F., Sherr, B. F., Sherr, E. B., and Cole, J. J., Lewis Publishers, Boca Raton, 715-722, 1993.

Lapernat, P. E., Gasparini, S., and Daro, N.: Possible impact of copepods on the dissolution of calcium carbonate. 3rd International Zooplankton Production Symposium. Gijon, Spain, 20-23 May, p.172, 2003.

10 Mayzaud, P. and Mayzaud, O.: Kinetic properties of digestive carbohydrases and proteases of zooplankton, Can. J. Fish. Aquat. Sci., 38, 535-543, 1981.

Milliman, J. D., Troy, P. J., Balch, W. M., Adams, A. K., Li, Y.-H., and Mackenzie, F. T.: Biologically mediated dissolution of calcium carbonate above the chemical lysocline? Deep-Sea Res. I, 46, 1653-1669, 1999.

Nejstgaard, J. C., Witte H. J., van der Wal P., and Jacobsen, A.: Copepod grazing during a mesocosm study of an Emiliania huxleyi (Prymnesiophyceae) bloom, Sarsia , 79, 369-377, 1994.

Pond, D. W., Harris, R. P., and Brownlee, C.: A microinjection technique using a pH-sensitive dye to determine the gut $\mathrm{pH}$ of Calanus helgolandicus, Mar. Biol., 123, 75-79, 1995.

Schulz, K. G., Riebesell, U., Bellerby, R., Biswas, H., Meyerhöfer, M., Müller, M., Egge, J., Nejstgaard, J., Neill, C., and Wohlers, J.: Build-up and decline of organic matter during PeECE III, 4, 4539-4570, 2007.

van Wheel, P. B.: Digestion in Crustacea, in: Chemical zoology, edited by: Florkin, M. and Scheer, B. T., Academic Press, New York, 97-115, 1970.

\section{BGD}

$5,1-23,2008$

Calcite dissolution by microzooplankton and copepod grazing

A. N. Antia et al.

Title Page

Abstract

Introduction

Conclusions

References

Tables

Figures

14

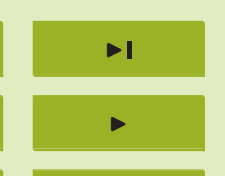

Back

Close

Full Screen / Esc

Printer-friendly Version

Interactive Discussion 


\section{BGD}

$5,1-23,2008$

Calcite dissolution by microzooplankton and copepod grazing

A. N. Antia et al.

Table 1. Results of laboratory grazing experiments with the rotifer Brachionus plicatilis, the heterotrophic flagellate Oxyrrhis marina and the copepod Acartia tonsa grazing on E. huxleyi, and the \% calcite dissolved.

\begin{tabular}{lcccc}
\hline Species & Experiment & $\begin{array}{c}\text { Ingestion rate } \\
\text { E. hux } \text { ind }^{-1} \mathrm{~d}^{-1}\end{array}$ & $\begin{array}{c}\text { E. hux residence } \\
\text { time }(\mathrm{h})\end{array}$ & $\begin{array}{c}\mathrm{Ca}_{\text {initial }} \\
\text { dissolved (\%) }\end{array}$ \\
\hline B. plicatilis & 1 & 10.7 & 2.2 & 55 \\
B. plicatilis & 2 & 13.4 & 1.8 & 45 \\
O. marina & 1 & 3.3 & 7.3 & 53 \\
O. marina & 2 & 3.7 & 6.5 & 37 \\
A. tonsa & 1 & 69 & 0.3 & 22 \\
A. tonsa & 2 & 90 & 0.3 & 5 \\
\hline
\end{tabular}


Table 2. Compilation of calcium key data from three mesocosms with varying $\mathrm{CO}_{2}$ treatments $\left(1 \times \mathrm{CO}_{2}=350 \mu \mathrm{atm}, 2 \times \mathrm{CO}_{2}=700 \mu \mathrm{atm}, 3 \times \mathrm{CO}_{2}=1050 \mu \mathrm{atm}\right)$. DAY=day after start of experiment, SS total particulate calcium standing stock at time $0, k$ specific growth coefficient, $g$ specific grazing coefficient, SE standard error of the regression coefficients $(k, g)$, significance level ( $\left.{ }^{\star} p<0.05,{ }^{\star \star} p<0.01,{ }^{\star \star \star} p<0.001\right), \mathrm{R}^{2}$ correlation coefficient, $n$ number of means used for the calculation of $k$ and $g$, SS GRAZ \% dynamic standing stock grazed per day.

\begin{tabular}{|c|c|c|c|c|c|c|c|c|c|}
\hline & DAY & $\begin{array}{r}\mathrm{SS} \\
\mu \mathrm{mol} \mathrm{Cal}^{-1}\end{array}$ & $\begin{array}{c}k \\
d^{-1}\end{array}$ & SE & $\begin{array}{c}g \\
d^{-1}\end{array}$ & SE & $\mathrm{R}^{2}$ & $n$ & $\begin{array}{r}\text { SS GRAZ } \\
\%\end{array}$ \\
\hline \multirow{4}{*}{$1 \times \mathrm{CO}_{2}$} & 1 & 2.65 & 0.54 & $\pm 0.09^{\star \star}$ & 0.92 & $\pm 0.14^{\star * *}$ & 0.82 & 12 & 60 \\
\hline & 7 & 4.78 & 1.07 & $\pm 0.08^{\star \star \star}$ & 0.34 & $\pm 0.11^{\star \star}$ & 0.48 & 12 & 29 \\
\hline & 13 & 12.50 & 0.22 & $\pm 0.03^{\star \star \star}$ & 0.12 & $\pm 0.04^{\star}$ & 0.44 & 12 & 12 \\
\hline & 20 & 11.95 & 0.11 & $\pm 0.05^{\star}$ & 0.27 & $\pm 0.07^{\star \star}$ & 0.60 & 12 & 23 \\
\hline \multirow[t]{4}{*}{$2 \times \mathrm{CO}_{2}$} & 2 & 1.69 & 0.94 & $\pm 0.10^{\star \star \star}$ & 0.82 & $0.14^{\star *}$ & 0.78 & 12 & 56 \\
\hline & 8 & 8.59 & 0.67 & $\pm 0.06^{\star \star *}$ & 0.39 & $0.09^{* *}$ & 0.67 & 12 & 32 \\
\hline & 14 & 10.48 & 0.36 & $\pm 0.04^{\star \star *}$ & 0.25 & $0.05^{\star *}$ & 0.68 & 12 & 22 \\
\hline & 21 & 8.73 & 0.17 & $\pm 0.01^{\star \star \star}$ & 0.13 & $0.01^{* \star *}$ & 0.93 & 9 & 12 \\
\hline \multirow[t]{4}{*}{$3 \times \mathrm{CO}_{2}$} & 3 & 1.89 & 1.03 & $\pm 0.07^{\star \star \star}$ & 0.92 & $0.10^{* \star *}$ & 0.90 & 12 & 60 \\
\hline & 9 & 8.77 & 0.54 & $\pm 0.07^{\star \star \star *}$ & 0.52 & $0.11^{* *}$ & 0.70 & 12 & 40 \\
\hline & 15 & 10.00 & 0.04 & \pm 0.04 & 0.12 & $0.05^{\star}$ & 0.39 & 11 & 11 \\
\hline & 22 & 7.18 & 0.14 & $\pm 0.02^{\star \star \star}$ & 0.05 & 0.03 & 0.25 & 12 & 5 \\
\hline
\end{tabular}

Calcite dissolution by microzooplankton and copepod grazing

A. N. Antia et al.

Title Page

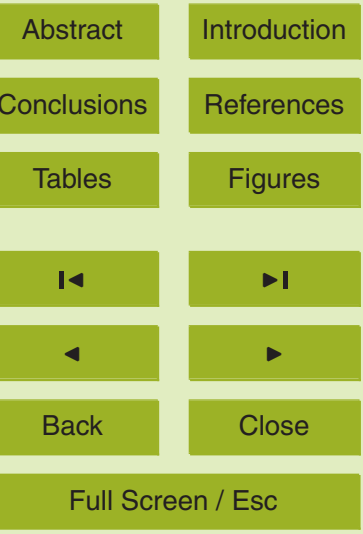

Printer-friendly Version

Interactive Discussion 
$5,1-23,2008$

Table 3. Compilation of calcium key data from three mesocosms with varying $\mathrm{CO}_{2}$ treatments $\left(1 \times \mathrm{CO}_{2}=350 \mu \mathrm{atm}, 2 \times \mathrm{CO}_{2}=700 \mu \mathrm{atm}, 3 \times \mathrm{CO}_{2}=1050 \mu \mathrm{atm}\right)$. DAY day of experiment, $\mathrm{SS}_{t o t}$ total particulate calcium standing stock at time $0, S_{\text {cells }}$ standing stock of particulate calcium in cells at time 0 , SS GRAZ \% dynamic standing stock grazed per day.

\begin{tabular}{rrrrr}
\hline & DAY & $\begin{array}{r}\mathrm{SS}_{\text {tot }} \\
\mu \text { moll }^{-1}\end{array}$ & $\begin{array}{r}\mathrm{SS}_{\text {cells }} \\
\mu \text { mol I }^{-1}\end{array}$ & $\begin{array}{r}\text { SS GRAZ } \\
\text { cell } \\
\%\end{array}$ \\
\hline $1 \times \mathrm{CO}_{2}$ & 1 & 2.65 & 0.51 & 113 \\
& 7 & 4.78 & 5.53 & 27 \\
& 13 & 12.50 & 0.78 & 47 \\
$2 \times \mathrm{CO}_{2}$ & 20 & 11.95 & 0.11 & 203 \\
& 2 & 1.69 & 0.69 & 73 \\
& 8 & 8.59 & 4.21 & 44 \\
$3 \times \mathrm{CO}_{2}$ & 14 & 10.48 & 0.46 & 66 \\
& 21 & 8.73 & 0.15 & 72 \\
& 3 & 1.89 & 1.17 & 70 \\
& 9 & 8.77 & 5.13 & 53 \\
& 15 & 10.00 & 0.31 & 165 \\
& 22 & 7.18 & 0.18 & 32 \\
\hline
\end{tabular}

Calcite dissolution by microzooplankton and copepod grazing

A. N. Antia et al.

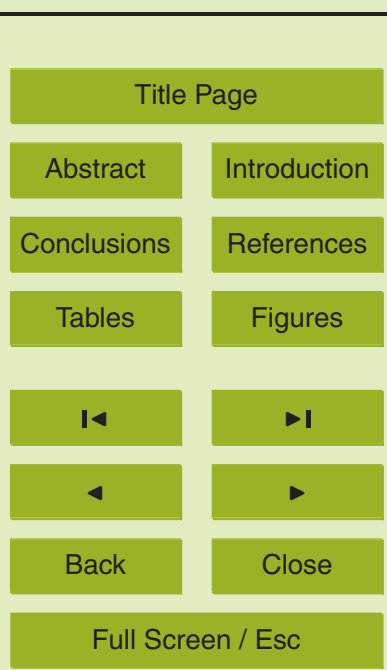

Printer-friendly Version

Interactive Discussion 

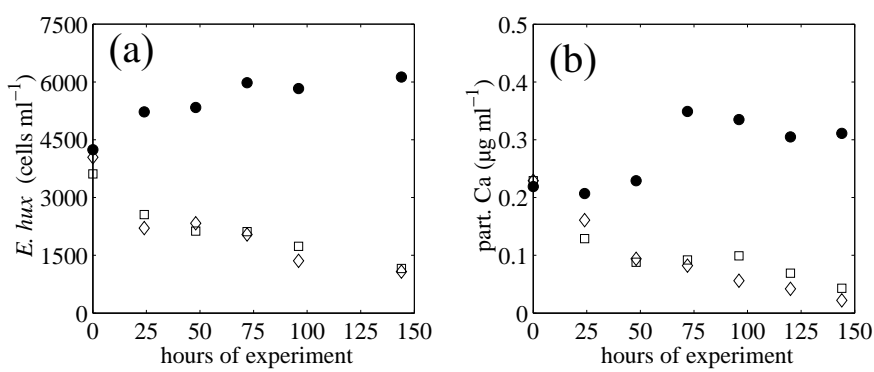

BGD

5, 1-23, 2008
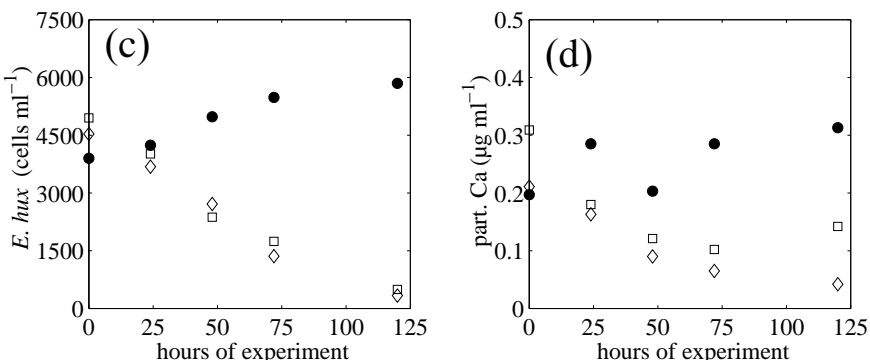

Calcite dissolution by microzooplankton and copepod grazing

A. N. Antia et al.
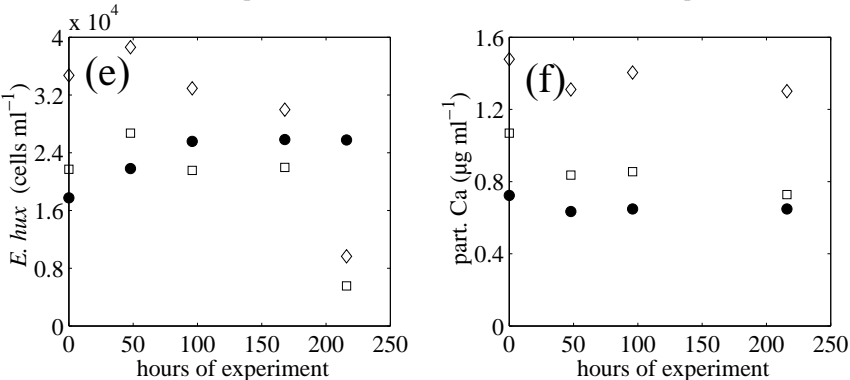

Title Page

Abstract

Introduction

Conclusions

References

Tables

Figures

14

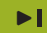

4

Back

Close

\section{Full Screen / Esc}

Printer-friendly Version

Fig. 1. Summary of laboratory experiments in which the rotifer Brachionus plicatilis (a) and (b), the heterotrophic flagellate Oxyrrhis marina (c) and (d) and the copepod Acartia tonsa (e) and (f) were fed on an exponentially growing culture of the coccolithophore Emiliania huxleyi. Filled

Interactive Discussion symbols show the control and open symbols the grazed culture. 

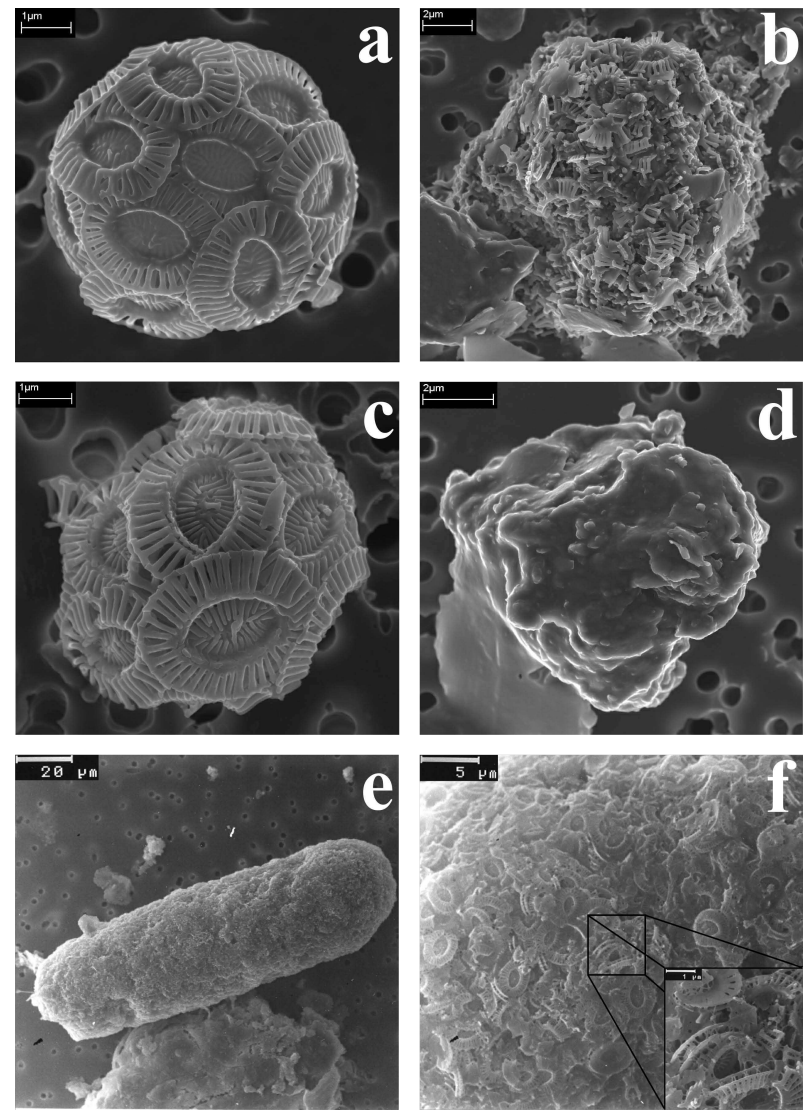

Fig. 2. Scanning electron micrographs of $E$. huxleyi cells in the control flasks (a) and (c) and at the end of the experiments after grazing by Brachionus plicatilis (b), Oxyrrhis marina (d) and Acartia tonsa showing excreted fecal pellet (e) with higher magnification in (f).

\section{BGD}

$5,1-23,2008$

Calcite dissolution by microzooplankton and copepod grazing

A. N. Antia et al.

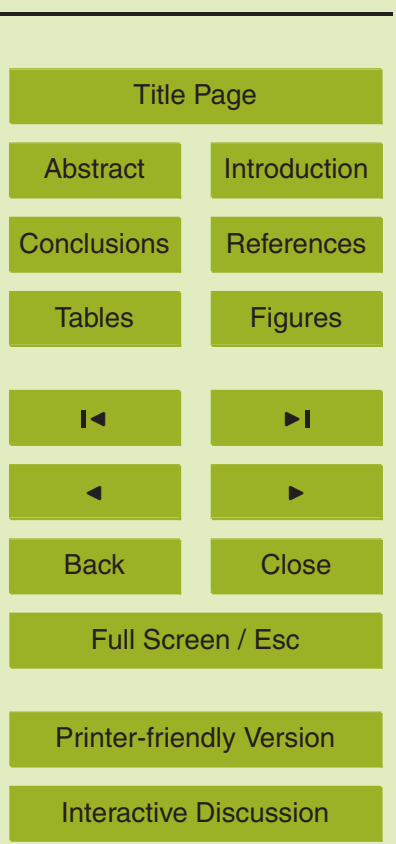




\section{BGD}

$5,1-23,2008$

Calcite dissolution by microzooplankton and copepod grazing

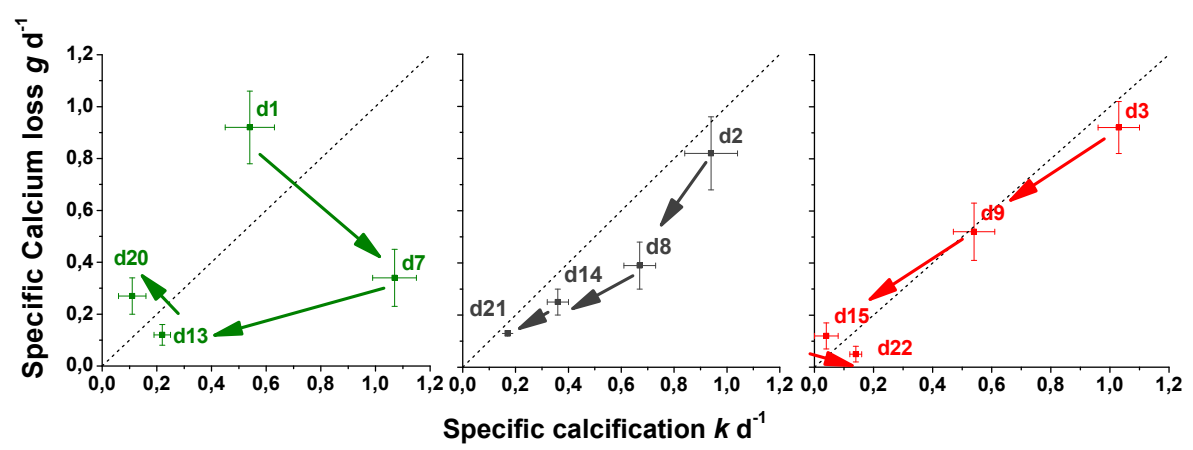

Fig. 3. Specific Ca-loss $(g)$ against specific calcification $(k)$ based on particulate calcite. Results are from three mesocosms with varying $\mathrm{CO}_{2}$ treatments $\left(1 \times \mathrm{CO}_{2}=350 \mu \mathrm{atm}\right.$, $\left.2 \times \mathrm{CO}_{2}=700 \mu \mathrm{atm}, 3 \times \mathrm{CO}_{2}=1050 \mu \mathrm{atm}\right)$. The dotted lines indicate steady state, arrows indicate the development over the bloom, values are labelled with the respective day of experiment.
A. N. Antia et al.

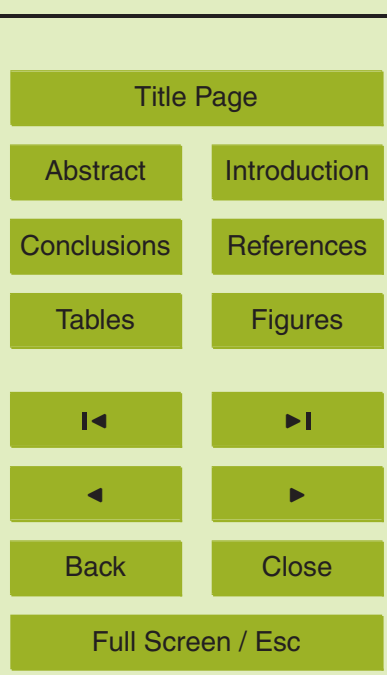

Printer-friendly Version 


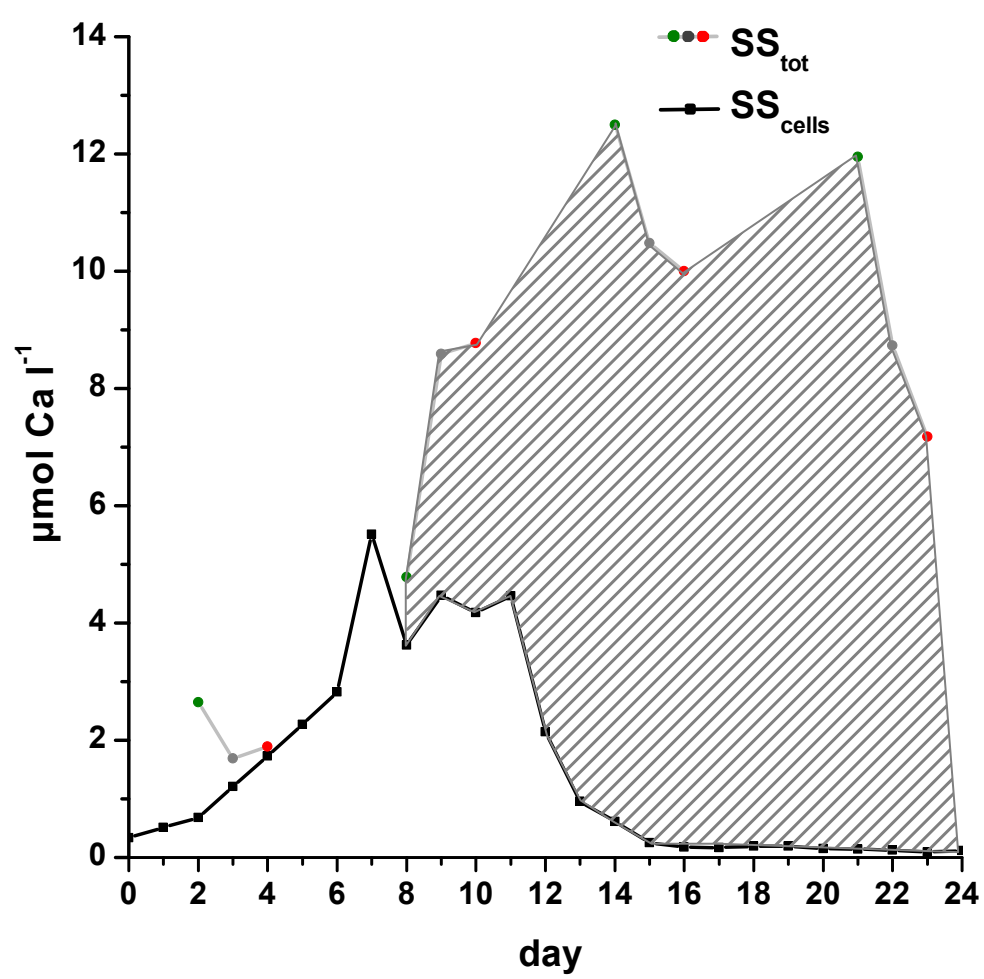

Fig. 4. Development of the $\mathrm{CaCO}_{3}$ standing stocks (1x, 2x, and $\left.3 \mathrm{x}\right)$ in the three mesocosm bags as in Fig. 3. Particulate calcite (in $\mu \mathrm{mol} \mathrm{Cal}^{-1}$ ) was differentiated into total particulate calcite standing stock $\left(\mathrm{SS}_{\text {tot }}\right)$ and particulate calcite in cells $\left(\mathrm{SS}_{\text {cells }}\right)$, and shows starting values of each experiment. The dashed area indicates the amount of the $\mathrm{SS}_{\text {tot }}$ in free coccoliths $\left(=\mathrm{SS}_{\mathrm{tot}}-\mathrm{SS}_{\text {cells }}\right)$.

\section{BGD}

$5,1-23,2008$

Calcite dissolution by microzooplankton and copepod grazing

A. N. Antia et al.

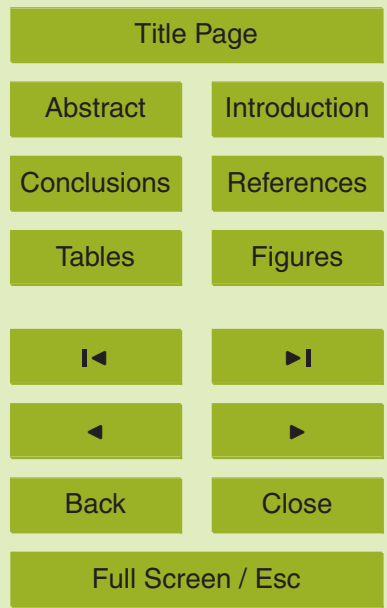

Printer-friendly Version

Interactive Discussion 